\title{
Studi Residu Antibiotika dan Kualitas Mikrobiologi Telur Ayam Konsumsi yang Beredar di Kota Administrasi Jakarta Timur
}

\author{
Study of Antibiotic Residue and Microbiological Quality of Commercial Eggs Sold in Administrative City of \\ East Jakarta
}

\author{
Anton $^{1}$, E. Taufik ${ }^{2 *}$, \& Z. Wulandari ${ }^{2}$ \\ ${ }^{1}$ Program Magister Ilmu Produksi dan Teknologi Peternakan, Fakultas Peternakan, IPB Universty \\ ${ }^{2}$ Departemen Ilmu Produksi dan Teknologi Peternakan, Fakultas Peternakan, IPB University \\ Jl. Agatis, Kampus IPB Darmaga Bogor 16680, Indonesia \\ *Corresponding author: epitaufik@apps.ipb.ac.id \\ (Received 06-08-2020; Revised 21-09-2020; Accepted 15-10-2020)
}

\begin{abstract}
Chicken eggs are fairly high in nutritional content, especially in proteins. Usually, antibiotics are used in disease prevention and treatment program at the layer chicken farms. The use of antibiotics are still not according to the direction of use. Egg production is also susceptible to bacterial contamination. Therefore, the objective of this study was to analyze the presence of kanamycin residue, the microbiological quality, and to evaluate potential risk factors associated with the microbiological quality of chicken eggs in the administration city of East Jakarta. The samples were 100 eggs taken from 21 traditional markets and 4 supermarkets in the administration city of East Jakarta. Kanamycin residue tested using bioassay method based on SNI 7424: 2008 and the microbiological quality method used based on SNI 3926: 2008. Data were analyzed using descriptive analysis univariate Chi-Square test to determine the effect of potential risk factors on the quality of microbiological quality and logistic regression models to analyze the effect of potential risk factors without looking at the interaction of other factors. The results showed that kanamycin residues were detected in $\mathbf{2 6 . 1 9 \%}$ of eggs from traditional markets and $31.25 \%$ eggs from supermarkets in the administration city of East Jakarta. The median value of TPC, coliform and E.coli were $0.7 \mathrm{log} \mathrm{cfu} / \mathrm{g}, 1.5 \mathrm{MPN} / \mathrm{g}$, and $1.5 \mathrm{MPN} / \mathrm{g}$, respectively, whilst Salmonella sp test was negative. It can be concluded that kanamycin residues still found in the markets and the microbiological quality were below the maximum contamination limit based on SNI 3926:2008 and egg cleanness was a risk factor for coliform contamination.
\end{abstract}

Keywords: antibiotic residue, microbiology, egg quality, risk factor, East Jakarta

\section{ABSTRAK}

Telur ayam memiliki kandungan gizi yang cukup tinggi, terutama dari segi protein dan nilai cerna oleh tubuh. Biasanya dalam program pengobatan dan pencegahan penyakit di peternakan digunakan antibiotika. Penggunaan antibiotika pada peternakan masih tidak sesuai dengan aturan pemakaian. Kerusakan pada telur dapat disebabkan oleh mikroorganisme yang diawali dengan masuknya mikroorganisme ke dalam telur. Penelitian ini dilakukan untuk menganalisa keberadaan residu antibiotika aminoglikosida, dan kualitas mikrobiologi serta mengevaluasi faktor-faktor risiko potensial yang terkait dengan mutu mikrobiologis telur ayam konsumsi di Wilayah Kota Jakarta Timur Provinsi DKI Jakarta. Telur yang digunakan sebanyak 100 sampel yang diambil dari 21 pasar tradisional dan 4 supermarket di kota administrasi Jakarta Timur. Pengujian residu kanamisin menggunakan metode bioassay berdasarkan SNI 7424:2008 dan pengujian kualitas mikrobiologis pada telur berdasarkan SNI 3926:2008. Pengolahan data menggunakan analisa deskriptif, uji Chi-Square univariat untuk mengetahui pengaruh faktor risiko potensial dengan kualitas mutu mikrobiologi dan model regresi logistik untuk menganalisa pengaruh faktor risiko potensial tanpa melihat interaksi dari faktor yang lain. Hasil penelitian ditemukan residu kanamisin sebanyak $26.19 \%$ dari pasar tradisional dan $31.25 \%$ dari supermarket di kota administrasi Jakarta Timur. Nilai median cemaran TPC, coliform dan $E$. coli adalah $0.7 \mathrm{log} \mathrm{cfu} / \mathrm{g}, 1.5 \mathrm{NPM} / \mathrm{g}$, dan $1.5 \mathrm{NPM} / \mathrm{g}$ serta hasil cemaran Salmonella sp. adalah negatif. Hasil penelitian menunjukkan bahwa masih ditemukan residu antibiotika kanamisin, kualitas mikrobiologi berada dibawah batas cemaran maksimum berdasarkan SNI 3926:2008 dan faktor kebersihan telur merupakan faktor risiko untuk cemaran bakteri coliform.

Kata kunci: residu antibiotika, mikrobiologi, kualitas telur, faktor resiko, Jakarta Timur. 


\section{PENDAHULUAN}

Kebutuhan protein hewani meningkat seiring dengan meningkatnya jumlah penduduk dan pendapatan perkapita penduduk. Telur merupakan produk peternakan yang memberikan sumbangan terbesar bagi tercapainya kecukupan gizi masyarakat. Telur ayam memiliki kandungan gizi yang cukup tinggi, terutama dari segi protein dan nilai cerna oleh tubuh. Telur yang biasa dikonsumsi adalah telur hasil produksi ayam petelur atau ayam ras. Berdasarkan data BPS (2019a) pada tahun 2018, produksi telur ayam ras di Indonesia mencapai 1,644,460 ton. Konsumsi telur ayam meningkat dalam kurun waktu enam tahun terakhir. Dibandingkan tahun 2017, konsumsi telur ayam meningkat sebesar $1.58 \%$ dari pada tahun 2018 dan menurut DKPKP (2018) konsumsi telur ayam di Provinsi DKI Jakarta adalah $24.7 \mathrm{~g} / \mathrm{kapita} / \mathrm{hari}$.

Penggunaan antibiotika sebagai growth promotor di Indonesia sudah dilarang berdasarkan Permentan Nomor 14 Tahun 2017 tentang KlasifikasiObatHewanyang menyatakan bahwa pada pakan tidak boleh ada campuran antibiotika di dalamnya. Biasanya dalam program pengobatan dan pencegahan penyakit di peternakan digunakan antibiotika. Penggunaan antibiotika pada peternakan masih tidak sesuai dengan aturan pemakaian. Akumulasi antibakteri di jaringan tubuh atau telur akibat penggunaan obat-obatan dan dikenal sebagai residu. Antibiotika yang digunakan tanpa memperhatikan waktu henti obat dapat menyebabkan residu antibiotika pada pangan asal hewan (Meutia et al. 2016 dan Ezenduka et al. 2011).

Salah satu golongan dari antibiotika yang biasa digunakan adalah golongan aminoglikosida. Antibiotika ini digunakan karena sifat antibakteri yang kuat, polaritas tinggi dan dapat larut dalam air. Jenis aminoglikosida seperti streptomisin, kanamisin, dan gentamisin akan berada seperti bentuk aslinya tetapi bukan metabolit pada tubuh manusia, akibatnya residu akan memberikan efek seperti ototoxicity dan toksisitas ginjal (Xu et al. 2019). Paparan antibiotika yang lama dapat berbahaya untuk kesehatan, karena dapat menyebabkan resistensi bakteri terhadap antibiotika, terutama antibiotika aminoglikosida (Farouk et al. 2015). Berdasarkan beberapa hasil penelitian menyebutkan bahwa penggunaan antibiotika dapat menyebabkan resistensi bakteri patogen yang dapat berpengaruh negatif terhadap kesehatan manusia berupa keracunan ataupun alergi (Dibner dan Richards 2005).

Telur konsumsi adalah telur ayam yang belum mengalami proses fortifikasi, pendinginan, pengawetan dan proses pengeraman (BSNI 2008). Telur dapat mengalami kerusakan, baik kerusakan fisik maupun kerusakan yang disebabkan oleh pertumbuhan mikroba. Ketersedian telur yang selalu ada dan memiliki nilai gizi tinggi harus diimbangi dengan pengetahuan masyarakat tentang kualitas telur dan penanganan telur untuk memperlambat penurunan kualitas telur karena sifat telur yang mudah rusak, tidak bertahan lama dan cepat mengalami penurunan kualitas (Purwati et al. 2015).

Kerusakan pada telur dapat disebabkan oleh mikroorganisme yang diawali dengan masuknya mikroorganisme ke dalam telur melalui pori-pori kerabang telur (Messens et al. 2005). Masuknya bakteri ke dalam telur setelah telur berada di luar tubuh induknya dapat berasal dari kotoran yang menempel pada kulit telur yang banyak mengandung bakteri perusak. Meskipun telur memiliki kerabang yang relatif tebal tetapi kerabang tersebut mempunyai banyak pori-pori yang dapat memungkinkan bakteri dapat masuk ke dalam telur, atau terjadinya pertukaran gas dari luar ke dalam sehingga dapat mengubah kualitas isi telur. Tebal atau tipisnya kerabang telur dapat dipengaruhi oleh strain ayam, pakan, stres dan penyakit pada induk (Hargitai et al. 2011).

Kerusakan telur oleh bakteri terjadi karena bakteri masuk ke dalam telur sejak berada di dalam maupun sudah berada di luar tubuh induknya, misalnya induk menderita salmonelosis, maka telur akan mengandung bakteri Salmonella $s p$. Kontaminasi dari luar berupa kotoran yang menempel yang banyak mengandung coliform dan E.coli. Wilayah kota Jakarta Timur merupakan wilayah yang paling tinggi jumlah penduduknya di Provinsi DKI Jakarta, menurut data dari BPS (2019b) adalah 2,916,020 jiwa. Banyaknya penduduk di Jakarta Timur dapat menjadi risiko yang besar pada residu antibiotika dan kualitas mutu fisik maupun mikrobiolgois telur ayam yang dikonsumsi. Penelitian ini bertujuan untuk menganalisa keberadaan residu antibiotika aminoglikosida, dan kualitas mikrobiologi serta mengevaluasi faktor-faktor risiko potensial yang terkait dengan mutu mikrobiologis telur ayam konsumsi di Wilayah Kota Jakarta Timur Provinsi DKI Jakarta.

\section{MATERI DAN METODE}

\section{Waktu dan Lokasi Penelitian}

Penelitian ini dilaksanakan pada bulan Januari sampai dengan Februari 2020. Pengujian kualitas mikrobiologis dan uji tapis (bioassay) residu antibiotika telur dilakukan di Laboratorium Kesehatan Masyarakat Veteriner, UPT Pusat Pelayanan Kesehatan Hewan dan Peternakan Provinsi DKI Jakarta.

\section{Materi Penelitian}

Penelitian ini menggunakan telur ayam yang diambil dari pasar atau pedagang telur di Wilayah Kota Administrasi Jakarta Timur Provinsi DKI Jakarta.

\section{Prosedur Penelitian}

Metode yang digunakan dalam penelitian ini adalah cross-sectional survei. Pengambilan sampel pasar ditentukan secara proporsional dari total pasar tradisional dan supermarket yang ada di kota administrasi Jakarta Timur. Target pengambilan sampel adalah telur ayam konsumsi yang dijual dipasar tradisional dan supermarket. Ukuran sampel ditentukan dengan software Win Episcope 2.0 berdasarkan estimasi prevalensi. Sebagai penyebab penyakit yang berbahaya, prevalensi Sallmonella $s p$. digunakan sebagai prevalensi yang diharapkan. Asumsi prevalensi Salmonella sp. menggunakan hasil penelitian dari Singh et al. (2010) yaitu $4.8 \%$. Dengan tingkat kepercayaan 95\%, dan tingkat kesalahan sebesar $5 \%$ maka banyaknya sampel yang dibutuhkan sebanyak 71 sampel 
dan dibulatkan menjadi 100 sampel untuk menghindari lost to follow up. Lokasi pasar yang akan diambil sampelnya dapat dilihat pada Tabel 1.

Tabel 1. Target Pasar Tradisonal dan Pasar Swalayan di Jakarta Timur

\begin{tabular}{clcc}
\hline No. & Jenis pasar & Jumlah pasar & Besaran sampel \\
\hline 1 & Pasar Tradisional & 21 & 82 \\
2 & Supermarket & 4 & 16 \\
\hline
\end{tabular}

\section{Uji Tapis (Screening Test) Residu Antibiotika}

Metode uji tapis residu antibiotika pada telur ayam mengacu pada Standar Nasional Indonesia (SNI) 7424 tahun 2008 tentang Metode uji tapis (screening test) residu antibiotika pada daging, telur dan susu secara bioassay.

\section{Uji Kualitas Mikrobiologi}

Metode pengujian kualitas mikrobiologi pada telur ayam mengacu pada Standar Nasional Indonesia (SNI) 3926 tahun 2008 tentang metode pengujian cemaran mikroba dalam daging, telur dan susu serta hasil olahannya.

\section{Faktor Risiko Potensial dari Kuesioner}

Informasi mengenai faktor risiko potensial tentang kualitas mutu dan residu antibiotika, dikumpulkan dengan menggunakan kuesioner. Semua informasi dikumpulkan selama kunjungan di pasar. Ada empat faktor risiko potensial yang diperoleh dari hasil pengamatan di pasar dan ditampilkan pada Tabel 2.

\begin{tabular}{llll}
\multicolumn{2}{l}{ Tabel 2. Faktor Potensial Risiko Hasil Pengamatan di Pasar } \\
\hline No. & \multicolumn{1}{c}{ Faktor } & \multicolumn{1}{c}{ Deskripsi } & \multicolumn{1}{c}{ Level } \\
\hline 1 & $\begin{array}{l}\text { Tempat Display } \\
\text { Telur }\end{array}$ & $\begin{array}{l}\text { Bahan tempat display } \\
\text { telur }\end{array}$ & $\begin{array}{l}\text { kayu } \\
\text { tray plastik } \\
\text { tray karton }\end{array}$ \\
2 & Paparan Matahari & Terkena sinar matahari & $\begin{array}{l}\text { terpapar } \\
\text { tidak }\end{array}$ \\
3 & Pembersihan & Kebersihan telur & bersih \\
& Telur & & sedikit \\
& & & $\begin{array}{l}\text { noda } \\
\text { banyak } \\
\text { noda }\end{array}$ \\
& & & AC \\
& & Penyejuk & Pemberian penyejuk \\
Ruangan & ruangan & tidak \\
\hline
\end{tabular}

\footnotetext{
Analisis Data

Analisis data yang dilakukan adalah analisis deskriptif dengan menyajikan hasil uji dalam bentuk tabel (Mattjik dan Sumertajaya 2006). Analisis data dilakukan dengan menggunakan program Microsoft Excel 2013. Uji Chi-Square univariat dilakukan untuk mengetahui pengaruh faktor risiko potensial dengan kualitas mutu mikrobiologi telur ayam konsumsi. Model regresi logistik digunakan untuk menganalisa pengaruh faktor risiko potensial tanpa melihat interaksi dari faktor yang lain. Uji Mann Whitney atau uji Kruskall Wallis digunakan untuk menganalisa hasil
}

uji mikrobiologi antar lokasi dan antar faktor risiko potensi (Petrie dan Watson 2013). Program SPSS versi 17.0 telah digunakan untuk semua uji-uji statistik.

\section{HASIL DAN PEMBAHASAN}

\section{Residu Antibiotika Kanamisin}

Hasil screening test dengan bioassay dari total 100 sampel telur ayam menunjukkan bahwa 27 sampel telur ayam tersebut memberikan hasil positif terhadap residu antibiotika golongan aminoglikosida yaitu kanamisin. Berdasarkan $\mathrm{Xu}$ et al. (2019) Maximum Residue Limits (MRL) dari antibiotika kanamisin pada telur ayam di Jepang adalah $0.5 \mathrm{mg} / \mathrm{kg}$ (ppm).

Hasil penelitian ini merupakan pertama kalinya residu kanamisin dalam sampel telur di wilayah Walikota Jakarta Timur yang menggunakan screening test dengan metode bioassay. Hasil uji residu antibiotika kanamisin menunjukan bahwa masih ditemukan antibiotika kanamisin pada telur ayam baik dari supermarket ataupun pasar tradisional. Sebanyak $31.25 \%$ telur ayam dari supermarket dan $26.19 \%$ dari pasar tradisional mengandung residu antibiotika kanamisin (Tabel 3). Hasil penelitian Hakimzadegan et al. (2014) di kota Tabriz, Iran menunjukkan bahwa dari 60 sampel telur uji, 18 sampel ternyata positif mengandung antibiotika, dengan 11 sampel $(61.11 \%)$ positif jenis makrolida, 4 sampel $(22.22 \%)$ positif jenis aminoglikosida dan 3 sampel (16.66\%) positif jenis tetrasiklin. Begitu juga hasil penelitian Dewi et al. (2014) di Provinsi Bali, NTB dan NTT menunjukkan bahwa masih ditemukan 0.3-9.15\% antibiotika golongan penisilin, tetrasiklin, aminoglikosida dan makrolida pada sampel telur ayam, itik dan puyuh.

Tabel 3. Hasil Screening test Residu Antibiotika dengan Bioassay pada telur ayam di Jakarta Timur.

\begin{tabular}{lcc}
\hline Type Pasar & \multicolumn{2}{c}{ Residu Kanamisin } \\
\cline { 2 - 3 } & Negatif & Positif \\
\hline Pasar Tradisional & $62(73.81 \%)$ & $22(26.19 \%)$ \\
Supermarket & $11(68.75 \%)$ & $5(31.25 \%)$ \\
Total & 73 & 27 \\
\hline
\end{tabular}

Hasil pengujian residu antibiotika pada telur ayam konsumsi di wilayah Walikota Jakarta Timur menunjukkan ditemukan telur yang positif mengandung residu kanamisin. Kanamisin merupakan termasuk dalam golongan antibiotika aminoglikosida, golongan ini banyak digunakan sebagai pengobatan infeksi saluran pencernaan dan pernafasan (CVMP 2018). Pada penelitian lain pada telur ayam menggunakan metode bioassay, golongan aminoglikosida terdeteksi sebagai kontaminan minor (Chowdhury et al. 2015, Shahbazi et al. 2015).

Kandungan residu antibiotika yang terdapat pada produk hasil ternak seperti daging telur dan susu disebabkan oleh penggunaan antibiotika yang luas untuk pengobatan menjadi perhatian kesehatan masyarakat. Hal ini dapat mengakibatkan manusia yang konsumsi dari produk ternak yang terkontaminasi oleh residu antibiotika dapat 
menyebabkan reaksi alergi dan dapat mempengaruhi sistem imun manusia. (Hakimzadegan et al. 2014).

\section{Kualitas Mikrobiologi}

Sebagai sumber protein yang mudah menjadi media tumbuh bagi bakteri, telur harus dijaga kualitasnya. Kualitas mikrobiologi telur konsumsi berdasarkan SNI 3926:2008 tentang telur ayam konsumsi adalah nilai kandungan Total Plate Count (TPC), coliform, E.coli dan Salmonella.

Mengacu dari Taufik (2007) maka untuk pencacahan sampel yang tidak menghasilkan pertumbuhan bakteri (hasil negatif) dicatat dengan setengah dari batas deteksi metode isolasi bakteri (untuk TPC 10:2 = 5 koloni $=\log$ 0.70; untuk coliform dan E.coli $3: 2=1.5 \mathrm{MPN}$ ). Tabel 4 menunjukkan kompilasi beberapa nilai statistika deskriptif dari hasil uji mikrobiologi telur ayam konsumsi. Nilai median keseluruhan dari TPC adalah $0.70 \mathrm{log} \mathrm{cfu} / \mathrm{g}$ dan untuk median coliform dan E.coli adalah $1.5 \mathrm{MPN} / \mathrm{g}$. Secara statistik median hasil uji TPC, coliform dan E.coli pada telur ayam dari kedua jenis pasar ini tidak berbeda nyata $(\mathrm{P}<0.05)$

Berdasarkan Gambar 1, 2, dan 3 dapat dilihat bahwa cemaran mikroba pada telur ayam di kedua jenis pasar di wilayah Jakarta Timur telah memenuhi standar mutu mikrobiologis telur ayam konsumsi berdasarkan SNI 3926:2008. Dengan kata lain, cemaran yang terdeteksi masih berada dibawah standar maksimum cemaran mikroba telur yaitu $5 \log \mathrm{cfu} / \mathrm{g}, 100 \mathrm{MPN} / \mathrm{g}$ dan $50 \mathrm{MPN} / \mathrm{g}$ untuk masing-masing jenis cemaran mikroba TPC, coliform dan E.coli.

Tabel 5, 6, dan 7 merangkum nilai cemaran mikrobiologi pada telur konsumsi di setiap level faktor risiko yang berasal dari kuesioner yang digunakan. Dari empat faktor risiko potensial yang dikaji, faktor kebersihan telur menunjukkan perbedaan yang nyata $(\mathrm{P}<0.05)$ pada cemaran coliform dan E.coli. Perbedaan nyata menunjukkan adanya pengaruh pada setiap level dari faktor risiko potensial terhadap nilai cemaran coliform dan E.coli pada telur ayam.

Tabel 4. Nilai statistik dari uji mikrobiologi telur ayam di wilayah kota Jakarta Timur.

\begin{tabular}{|c|c|c|c|c|c|c|}
\hline \multirow[t]{2}{*}{ No } & \multirow[t]{2}{*}{ Uji Mikrobiologi } & \multirow[t]{2}{*}{ Statistik } & \multirow[t]{2}{*}{ Keseluruhan } & \multicolumn{2}{|c|}{ Pasar } & \multirow[t]{2}{*}{ Nilai P } \\
\hline & & & & Tradisional & Supermarket & \\
\hline \multirow[t]{4}{*}{1} & TPC & Median & 0.70 & 0.70 & 0.70 & 0.562 \\
\hline & $(\log \mathrm{cfu} / \mathrm{g})$ & Maks. & 2.29 & 2.06 & 2.29 & \\
\hline & & Min. & 0.70 & 0.70 & 0.70 & \\
\hline & & IQR & 0.18 & 0.27 & 0.14 & \\
\hline \multirow[t]{4}{*}{2} & Coliform & Median & 1.50 & 1.50 & 1.50 & 0.535 \\
\hline & (MPN/g) & Maks. & 43.00 & 43.00 & 1.50 & \\
\hline & & Min. & 1.50 & 1.50 & 1.50 & \\
\hline & & IQR & 0.00 & 0.00 & 0.00 & \\
\hline \multirow[t]{4}{*}{3} & E. coli & Median & 1.50 & 1.50 & 1.50 & 0.663 \\
\hline & (MPN/g) & Maks. & 43.00 & 43.00 & 1.50 & \\
\hline & & Min. & 1.50 & 1.50 & 1.50 & \\
\hline & & IQR & 0.00 & 0.00 & 0.00 & \\
\hline 4 & $\begin{array}{l}\text { Salmonella } \\
(/ 25 \mathrm{~g})\end{array}$ & & Negatif & Negatif & Negatif & \\
\hline
\end{tabular}

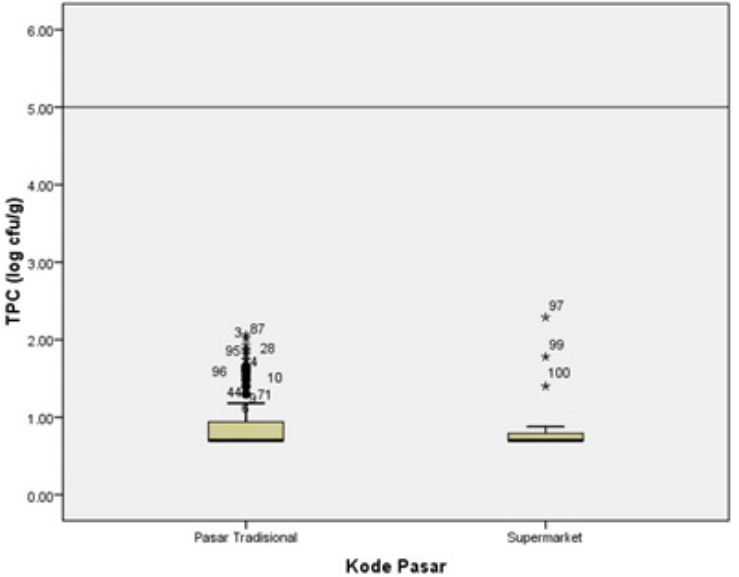

Gambar 1. Grafik boxplot TPC pada telur dari pasar dibandingkan dengan batas maksimum cemaran mikroba berdasarkan SNI 3926:2008

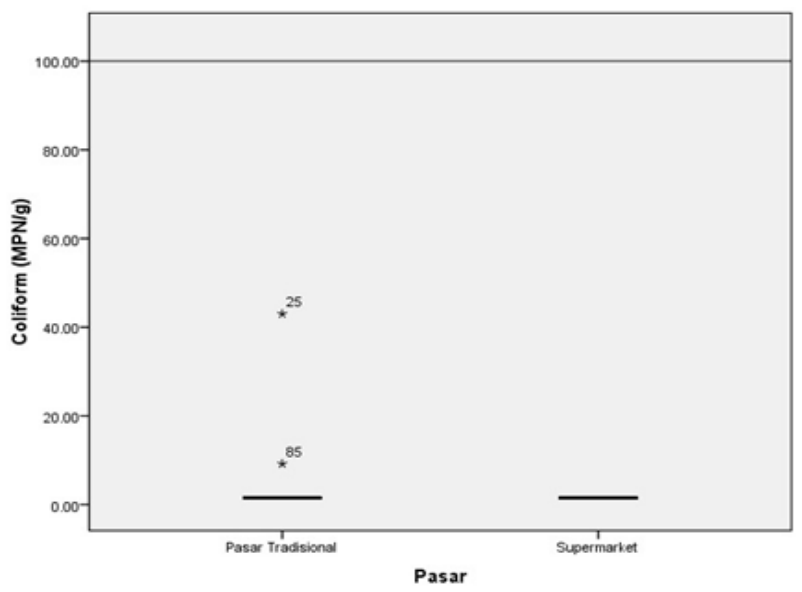

Gambar 2. Grafik boxplot cemaran coliform pada telur dari pasar dibandingkan dengan batas maksimum cemaran mikroba berdasarkan SNI 


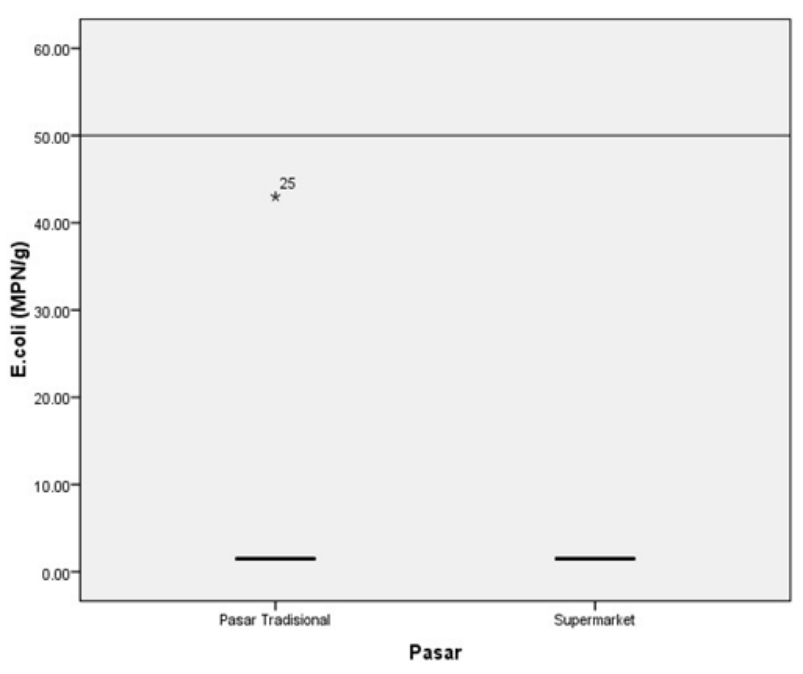

Gambar 3. Grafik boxplot cemaran E.coli pada telur dari pasar dibandingkan dengan batas maksimum cemaran mikroba berdasarkan SNI 3926:2008

Tabel 5. Nilai TPC antara setiap faktor risiko pada telur ayam di wilayah Jakarta Timur

\begin{tabular}{lcccc}
\hline Faktor & Level & $\mathrm{n}$ & Median & Nilai P \\
\hline Tempat Display & Kayu & 35 & 0.70 & 0.116 \\
& Plastik & 19 & 0.70 & \\
& Karton & 46 & 0.70 & \\
Paparan Matahari & Ya & 24 & 0.70 & 0.332 \\
& Tidak & 76 & 0.70 & \\
Kebersihan Telur & bersih & 71 & 0.70 & 0.622 \\
& sedikit & 25 & 0.70 & \\
& noda & & & \\
& banyak & 4 & 0.79 & \\
& noda & & & \\
AC & Ya & 16 & 0.70 & 0.562 \\
& Tidak & 84 & 0.70 & \\
\hline
\end{tabular}

Tabel 6. Nilai cemaran coliform antara setiap faktor risiko pada telur ayam di wilayah Jakarta Timur

\begin{tabular}{lcccc}
\hline Faktor & Level & $\mathrm{n}$ & Median & Nilai P \\
\hline Tempat Display & Kayu & 35 & 1.50 & 0.773 \\
& Plastik & 19 & 1.50 & \\
& Karton & 46 & 1.50 & \\
Paparan Matahari & Ya & 24 & 1.50 & 0.396 \\
& Tidak & 76 & 1.50 & \\
Kebersihan Telur & bersih & 71 & 1.50 & 0.003 \\
& sedikit & 25 & 1.50 & \\
& noda & & & \\
& banyak & 4 & 1.50 & \\
& noda & & & \\
AC & Ya & 16 & 1.50 & 0.535 \\
& Tidak & 84 & 1.50 & \\
\hline
\end{tabular}

Tabel 7. Nilai cemaran E.coli antara setiap faktor risiko pada telur ayam di wilayah Jakarta Timur

\begin{tabular}{lcccc}
\hline Faktor & Level & $\mathrm{n}$ & Median & Nilai P \\
\hline Tempat Display & Kayu & 35 & 1.50 & 0.556 \\
& Plastik & 19 & 1.50 & \\
& Karton & 46 & 1.50 & \\
Paparan Matahari & Ya & 24 & 1.50 & 0.574 \\
& Tidak & 76 & 1.50 & \\
Kebersihan Telur & bersih & 71 & 1.50 & 0.000 \\
& sedikit & 25 & 1.50 & \\
& noda & & & \\
& banyak & 4 & 1.50 & \\
& noda & & & \\
AC & Ya & 16 & 1.50 & 0.663 \\
& Tidak & 84 & 1.50 & \\
\hline
\end{tabular}

Sesuai dengan penelitian Jones et al. (2012) bahwa telur yang kerabangnya kotor karena feces memiliki cemaran coliform sebanyak 359 isolat dan yang mengandung E.coli sebesar $8.05 \%$ pada bagian isi telurnya.

Tabel 8 menunjukkan nilai prevalensi cemaran mikroba dari telur konsumsi pada pasar secara keseluruhan, pasar tradisional dan supermarket. Nilai prevalensi secara keseluruhan pada coliform adalah $2 \%$, dan pada cemaran E.coli adalah 1\%. Nilai prevalensi coliform dan E.coli tertinggi hanya pada pasar tradisional dengan nilai $2.38 \%$ dan $1.19 \%$. Nilai prevalensi semua cemaran tersebut tidak berbeda nyata antara telur konsumsi yang dijual di pasar tradisional dan supermarket $(\mathrm{P}>0.05)$. Hasil studi ini berbeda dengan hasil penelitian El-Kholy et al. (2020) bahwa di kota Beni-Suef, Iran secara keseluruhan prevalensi coliform dan E.coli pada telur konsumsi adalah sebesar $22 \%$ dan $6 \%$.

Tabel 8. Nilai prevalensi cemaran coliform dan E.coli pada telur konsumsi di wilayah Jakarta Timur

\begin{tabular}{lccccc}
\hline $\begin{array}{l}\text { Uji } \\
\text { Mikrobiologi }\end{array}$ & Pasar & $\mathrm{n}$ & $\begin{array}{c}\text { Hasil } \\
\text { Positif }\end{array}$ & $\begin{array}{c}\text { Prev- } \\
\text { alensi } \\
(\%)\end{array}$ & Nilai P \\
\hline Coliform & Keseluruhan & 100 & 2 & $2.00 \%$ & 0.535 \\
& Tradisional & 84 & 2 & $2.38 \%$ & \\
& Supermarket & 16 & 0 & $0.00 \%$ & \\
E.coli & Keseluruhan & 100 & 1 & $1.00 \%$ & 0.663 \\
& Tradisional & 84 & 1 & $1.19 \%$ & \\
& Supermarket & 16 & 0 & $0.00 \%$ & \\
\hline
\end{tabular}

Data pada Tabel 9 menunjukkan prevalensi sampel positif coliform pada telur ayam konsumsi dari wilayah kota Jakarta Timur di setiap tingkat reisiko potensial. Dari keseluruhan faktor risiko potensial yang ada, hanya level pada faktor kebersihan telur yang menunjukkan perbedaan yang nyata $(\mathrm{P}<0.05)$ untuk prevalensi cemaran coliform pada telur. Selanjutnya diuji lebih lanjut dengan uji regresi logistik untuk mengetahui apakah faktor tersebut merupakan faktor risiko atau bukan. 
Tabel 9. Hasil penilaian hubungan antara prevalensi coliform dengan faktor risiko potensial (analisis univariat)

\begin{tabular}{lcccccc}
\hline Faktor & Level & $\mathrm{n}$ & $\mathrm{n}(-)$ & $\mathrm{n}(+)$ & $\%(+)$ & $\begin{array}{c}\text { Nilai } \\
\mathrm{P}\end{array}$ \\
\hline Display & Kayu & 35 & 34 & 1 & $2.86 \%$ & 0.769 \\
& Plastik & 19 & 19 & 0 & $0.00 \%$ & \\
& Karton & 46 & 45 & 1 & $2.17 \%$ & \\
PapMat & Tidak & 76 & 75 & 1 & $1.32 \%$ & 0.384 \\
& Ya & 24 & 23 & 1 & $4.17 \%$ & \\
Kebersihan & Bersih & 71 & 70 & 1 & $1.41 \%$ & 0.003 \\
& Sedikit & 25 & 25 & 0 & $0.00 \%$ & \\
& Noda & & & & & \\
& Banyak & 4 & 3 & 1 & $25.00 \%$ & \\
AC & Noda & & & & & \\
& Tidak & 84 & 82 & 2 & $2.38 \%$ & 0.533 \\
& Ya & 16 & 16 & 0 & $0.00 \%$ & \\
\hline
\end{tabular}

Tabel 10 menunjukkan hasil regresi logistik faktor kebersihan telur yang secara nyata terkait dengan prevalensi coliform dalam analisis univariat (Tabel 9). Odd Ratio (OR) tingkat kebersihan telur yang banyak noda nilainya lebih besar dari satu $(\mathrm{OR}=23.333)$ dan memiliki hubungan yang signifikan $(\mathrm{P}<0.05)$, dengan demikian sampel telur yang banyak noda memiliki peluang terkontaminasi coliform 23.333 kali nyata lebih tinggi dibandingkan dengan tingkat kebersihan telur yang bersih (faktor referensi). Dengan demikian, dapat disimpulkan bahwa tingkat kebersihan telur merupakan faktor risiko cemaran coliform pada telur.

Hal ini menunjukkan bahwa peningkatan bakteri coliform terjadi karena tingkat kebersihan telur yang kurang baik karena kotoran/feses atau pecahan telur lain yang menempel. Penempelan yang terjadi mengakibatkan kotoran, sampah dan debu menempel pada cangkang sehingga semakin lama akan dapat masuk ke dalam telur melalui pori-pori. Kebersihan lingkungan sekitar dan telur sendiri perlu diperhatikan karena mikroba dapat tumbuh dan berkembang dengan kondisi tertentu (Mutiarini et al. 2019).

Tabel 10. Hasil regresi logistik dari faktor yang berhubungan dengan tingkat prevalensi cemaran coliform pada telur

\begin{tabular}{lccc} 
Faktor & OR* & Nilai P & $\begin{array}{c}\text { Selang } \\
\text { Kepercayaan 95\% }\end{array}$ \\
\hline Kebersihan & & & \\
- Bersih & 1 & - & 0 \\
- Sedikit Noda & 0.000 & 0.998 & {$[0.000,0.000]$} \\
- Banyak Noda & 23.333 & 0.040 & {$[1.158,470.092]$} \\
\hline
\end{tabular}

$* \mathrm{OR}=$ Odd ratio

$\mathrm{OR}=1$ : tidak ada hubungan antara keberadaan indikator bakteri dengan faktor risiko

OR $>1$ : Faktor ini berhubungan positif dengan keberadaan bakteri indikator (faktor risiko)

OR $<1$ : Faktor ini berhubungan negatif dengan keberadaan bakteri indikator (faktor penghambat)
Data pada Tabel 11 menunjukkan sampel positif terkontaminasi E.coli pada telur ayam konsumsi dari wilayah kota Jakarta Timur di setiap tingkat risiko potensial. Dari keseluruhan faktor risiko potensial yang ada, hanya level pada faktor kebersihan menunjukkan perbedaan nyata $(\mathrm{P}<0.05)$ untuk prevalensi cemaran E.coli pada telur. Berdasarkan analisis univariat, faktor kebersihan telur menunjukkan perbedaan yang nyata antar levelnya untuk prevalensi cemaran E. coli. Selanjutnya, uji regresi logistik dilakukan untuk mengetahui apakah faktor tersebut merupakan faktor risiko atau bukan.

Tabel 11. Hasil penilaian hubungan antara prevalensi E. coli dengan faktor risiko potensial (analisis univariat)

\begin{tabular}{lcccccc}
\hline Faktor & Level & $\mathrm{n}$ & $\mathrm{n}(-)$ & $\mathrm{n}(+)$ & $\%(+)$ & Nilai P \\
\hline Display & Kayu & 35 & 35 & 0 & $0.00 \%$ & 0.553 \\
& Plastik & 19 & 19 & 0 & $0.00 \%$ & \\
& Karton & 46 & 45 & 1 & $2.17 \%$ & \\
PapMat & Tidak & 76 & 75 & 1 & $1.32 \%$ & 0.572 \\
& Ya & 24 & 24 & 0 & $0.00 \%$ & \\
Kebersihan & Bersih & 71 & 71 & 0 & $0.00 \%$ & 0.000 \\
& Sedikit & 25 & 25 & 0 & $0.00 \%$ & \\
& Noda & & & & & \\
& Banyak & 4 & 3 & 1 & $25.00 \%$ & \\
AC & Noda & & & & & \\
& Tidak & 84 & 83 & 1 & $1.19 \%$ & 0.661 \\
& Ya & 16 & 16 & 0 & $0.00 \%$ & \\
\hline
\end{tabular}

Tabel 12 menunjukkan hasil regresi logistik faktor kebersihan telur yang secara signifikan terkait dengan prevalensi E.coli dalam analisis univariat (Tabel 11). Tingkat kebersihan telur tidak memiliki hubungan yang signifikan dengan hasil prevalensi cemaran E.coli pada telur, sehingga dapat disimpulkan dalam studi ini, faktor kebersihan tidak dapat dinyatakan sebagai faktor risiko cemaran E.coli.

Namun demikian, data pada Tabel 12 menunjukkan nilai Odd Ratio (OR) pada level banyak noda bernilai $>1$ tetapi nilai $\mathrm{P}$ tidak menunjukkan hasil yang nyata, sehingga faktor kebersihan tidak dapat dikatakan sebagai faktor risiko bagi cemaran E.coli pada telur di studi ini. Nilai Odd Ratio yang tinggi pada level banyak noda dimungkinkan karena hasil positif E.coli hanya ditemukan pada 1 butir telur saja pada telur yang banyak noda, selain itu semuanya negatif. Sehingga nilai Odd Ratio $>1$ tetapi secara statistik tidak berbeda nyata.

Tabel 12. Hasil regresi logistik dari faktor yang berhubungan dengan tingkat prevalensi cemaran E. coli pada telur

\begin{tabular}{lccc}
\hline Faktor & OR & Nilai P & $\begin{array}{c}\text { Selang } \\
\text { Kepercayaan } \\
95 \%\end{array}$ \\
\hline Kebersihan & & & \\
- Bersih & 1 & - & 0 \\
- Sedikit Noda & 1.00 & 1.000 & {$[0.000,0.000]$} \\
- Banyak Noda & $538.491 .606,96$ & 0.997 & {$[0.000,0.000]$} \\
\hline
\end{tabular}


Hasil studi ini berbeda dengan hasil penelitian Khan et al. (2016) dan Ghasemian et al. (2011) bahwa sebanyak $37 \%$ ditemukan kontaminasi E.coli pada telur ayam yang dijual di pasar tradisional ataupun supermarket di kota Peshawar, Pakistan dan 19\% di kota Shahrekord, Iran. Perbedaan ini mungkin disebabkan oleh managemen, penanganan dan kondisi hygene dari kandang sampai ke pasar. Telur dapat terkontaminasi secara horisontal (melalui kerabang) atau vertikal (trans-ovarial) dan dapat menjadi sumber patogen potensial dalam etiologi foodborne disease (Stepien-Pysniak 2010).

\section{Angka Lempeng Total Bakteri / TPC (Total Plate Count)}

Nilai median jumlah cemaran TPC pada telur ayam konsumsi di wilayah Jakarta Timur adalah $0.70 \mathrm{log} \mathrm{cfu} / \mathrm{g}$, secara statistik nilai median TPC pada telur ayam tidak bebeda nyata pada kedua pasar tersebut. Cemaran mikroba pada telur ayam di pasar wilajah Jakarta Timur tidak melebihi mutu mikrobiologis telur ayam konsumsi berdasarkan SNI 3926:2008. Nilai cemaran TPC dari penelitian ini masih lebih rendah dari pada hasil penelitian dari Suharyanto et al. (2016) di wilayah Bogor yaitu 6.3-6.9 lg cfu/g dan El-Kholy et al. (2014) di negara Mesir sebesar $3.04 \mathrm{log} \mathrm{cfu} / \mathrm{g}$.

Menurut Suharyanto et al. (2016) tidak adanya perbedaan cemaran mikroba antar kelompok pasar menunjukkan kemungkinan umur telur yang berada di semua kelompok pasar memiliki umur simpan yang relatif sama. Cemaran mikroba diduga karena umur simpan telur yang telah lama karena melalui beberapa rantai tataniaga. Biasanya telur sampai ke konsumen terakhir telah melewati beberapa jalur distribusi yaitu produsen, distributor, pedagang pengumpul, dan pedagang eceran (Afiyah dan Rahmawati 2017).

\section{Salmonella sp.}

Dari 100 sampel yang diambil dari pasar di wilayah Jakarta Timur semua memberikan hasil negatif terhadap cemaran Salmonell sp. Hasil pengujian kualitas mikrobiologi Salmonella sp. telur ayam dapat dilihat pada Tabel 4. Telur ayam yang dijual di pasar tradisional dan supermarket di wilayah kota Jakarta Timur telah memenuhi standar yang ditetapkan, karena hasil penelitian ini menunjukkan bahwa dari total sampel telur yang diperiksa seluruhnya tidak mengandung bakteri Salmonella sp. Hasil ini menunjukkan kualitas telur yang dijual tersebut baik.

\section{Asosiasi Faktor Risiko Potensial Pencemaran Mikrobiologi}

Hasil dari kuesioner tentang faktor risiko potensial yang ada di pasar dapat dilihat bahwa median TPC, coliform dan E.coli pada telur ayam konsumsi tidak berbeda nyata pada setiap faktor risiko potensial. Hanya faktor kebersihan telur yang memberikan hasil berbeda nyata pada cemaran coliform dan E.coli. Hal ini sejalan dengan pendapat Baron dan Jan (2011) yang menyatakan bahwa cemaran mikrobiologi pada telur ayam sangat ditentukan dari kebersihan dari telur. Peternak ataupun pedagang yang melakukan pembersihan telur dapat menghindari kontaminasi bakteri.
Tingkat kebersihan telur menjadi satu-satunya faktor potensial yang memiliki hubungan yang nyata dengan kemunculan cemaran coliform dan E.coli. Tingkat kebersihan dengan noda yang banyak memiliki peluang yang nyata lebih tinggi untuk munculnya cemaran coliform dari pada tingkat kebersihan yang lain $(\mathrm{OR}=23.333, \mathrm{P}<0.05$, $95 \% \mathrm{CI}=1.158,470.092)$ tetapi tidak menjadi faktor risiko pada cemaran E.coli. Hal ini sejalan dengan hasil penelitian Sakti et al. (2012) dan Jones et al. (2012) bahwa tidak semua coliform terkandung didalamnya bakteri E.coli.

Walau nilai P tidak nyata sehingga tingkat kebersihan tdk dpt disimpulkan sbg faktor risiko cemaran $E$. coli pada studi ini, tetapi OR $>1$, hanya data prevalensi kurang baik, tetapi setidaknya menunjukkan ada kaitan antara tingkat kebersihan telur dengan cemaran E. coli. Terbukti dengan nyatanya hubungan tingkat kebersihan dengan cemaran coliform, dlm hal ini $E$. coli adalah anggota dari bakteri dari coliform, dengan demikian walaupun tingkat kebersihan tidak dapat disimpulkan sbgai faktor risiko untuk cemaran E. coli dalam studi ini, nilai OR $>1$ dan nyatanya hubungan faktor kebersihan dengan cemaran coliform (dimana $E$. coli adalah anggotanya), faktor kebersihan telur tidak kemudian lantas diabaikan untuk dijaga.

\section{KESIMPULAN}

Studi ini menunjukkan bahwa $27 \%$ telur ayam konsumsi yang beredar di wilayah kota administrasi Jakarta Timur, baik yang dijual di pasar tradisional maupun supermarket, masih ditemukan yang mengandung residu antibiotika kanamisin. Kualitas mikrobiologi berada dibawah batas cemaran maksimum berdasarkan SNI 3926:2008 dan faktor kebersihan telur merupakan faktor risiko untuk cemaran bakteri coliform.

\section{DAFTAR PUSTAKA}

Afiyah, D.N., \& Rahmawati, N. 2017. Kualitas Fisik dan Mikrobiologi Telur Ayam Ras di Pasar Tradisional kota kediri. Seminar Nasional Hasil Penelitian Universitas Kanjuruhan Malang.

Agustin, A.L.D. 2017. Tingkat cemaran bakteri dan deteksi residu antibiotika pada telur ayam layer dari peternakan GEMAS Kabupaten Lombok Utara. Jurnal Sangkareang Mataram. 3(3): 33-35

Anjarsari, B. 2010. Pangan Hewani. Yogyakarta (ID): Graha Ilmu.

Arisnawati, Y. \& Susanto, A. 2017. Identifikasi bakteri Salmonella sp. pada telur ayam ras (studi di pasar Pon Jombang). Jurnal Insan Cendekia. 5(1): 33-39.

Baron, F. \& Jan, S. 2011. Egg and egg product microbiology. Di dalam Van Immerseel F, Nys Y, Bain $\mathrm{M}$, editor. Improving the safety and quality of eggs and egg products. Woodhead Publishing. hlm 330-350.

Birowo. J, Sukada I.M., Suarjana, I.G.K. 2013. Perbandingan jumlah bakteri coliform pada telur ayam buras yang dijual di pasar bersanitasi baik dan buruk. Indonesia Medicus Veterinus. 2(3): 269-280.

[BPS] Badan Pusat Statistik. 2017. Kajian konsumsi 
bahan pokok tahun 2017. Jakarta (ID). Badan Pusat Statistik.

[BPS] Badan Pusat Statistik. 2019a. Distribusi perdagangan komoditas telur ayam ras indonesia tahun 2019. Jakarta (ID). Badan Pusat Statistik.

[BPS] Badan Pusat Statistik. 2019b. Provinsi DKI Jakarta dalam angka. Jakarta (ID). Badan Pusat Statistik.

[BSNI] Badan Standardisasi Nasional Indonesia. 2008. SNI. 2897:2008: Metode pengujian cemaran mikroba dalam daging, telur dan susu, serta hasil olahannya. Jakarta (ID). Badan Standardisasi Nasional.

[BSNI] Badan Standardisasi Nasional Indonesia. 2008. SNI. 3926:2008: Telur ayam konsumsi. Jakarta (ID). Badan Standardisasi Nasional.

[BSNI] Badan Standardisasi Nasional Indonesia. 2008. SNI. 7424:2008: metode uji tapis (screening test) residu antibiotika pada daging, telur dan susu secara bioassay. Jakarta (ID). Badan Standardisasi Nasional.

Chowdhury, S., Hassan, M. M., Alam, M., Sattar, S., Bari, M. S., Saifuddin, A. K. M., \& Hoque, M. A. 2015. Antibiotic residues in milk and eggs of commercial and local farms at Chittagong, Bangladesh. Veterinary world, 8(4): 467.

Committee for Medicinal Products for Veterinary Use (CVMP). 2018. Reflection paper on use of aminoglycosides in animals in the European Union: development of resistance and impact on human and animal health. European Medicines Agency. EMA/ CVMP/AWP/721118/2014. 1-44

Darmayani, S., Rosanty, A., \& Vanduwinata, V. 2017. Identifikasi bakteri Salmonella sp. pada telur yang dijual di pasar Kota Kendari Provinsi Sulawesi Tenggara. Biogenesis: Jurnal Ilmiah Biologi. 5(1): 21-26.

Dewi, A.A.S., Widdhiasmoro, N.P., Nurlatifah, I., Riti, N., \& Purnawati, D. 2014. Residu antibiotika pada pangan asal hewan, dampak dan upaya penanggulangannya. Buletin Veteriner. 36 (85): 23-33.

[DKPKP] Dinas Ketahananan Pangan, Kelautan dan Pertanian Provinsi DKI Jakarta. 2018. Laporan Analisis Pola Konsumsi Pangan Berdasarkan Data Survey Sosial Ekonomi Nasional Indonesia (Susesnas) Tahun 2017. Jakarta.

Dibner, J. J., \& Richards, J. D. 2005. Antibiotic growth promoters in agriculture: history and mode of action. Poultry science. 84(4): 634-643.

Ezenduka, E. V., Oboegbulem, S. I., Nwanta, J. A., \& Onunkwo, J. I. 2011. Prevalence of antimicrobial residues in raw table eggs from farms and retail outlets in Enugu State, Nigeria. Tropical Animal Health and Production. 43(3): 557-559.

El-Kholy, A.M, Hassan, G.M., \& Dalia, M.A. 2014. Microbiological quality of poultry farm table eggs in Beni-suef city, Egypt. Assiut Vet. Med. J. 60(142): 1013 .

El-Kholy, A.M., EL-Shinawy, S.H., Seliem, H., \& Zeinhom, M.A.M. 2020. Potential risk of some pathogens in table eggs. Journal of Veterinary Medical Research. 27(1): 52-65.

Etikaningrum, \& Iwantoro, S. 2017. Kajian residu antibiotika pada produk ternak unggas di Indonesia. Jurnal Ilmu Produksi dan Teknologi Hasil Peternakan. 5(1): 29-33.

Farouk, F., Azzazy, H.M., \& Niessen, W.M. 2015. Challenges in the determination of aminoglycoside antibiotics, a review. Analytica Chimica Acta. 890. 21-43.

Fibrianti, S.M, Suada, I.K., \& Rudyanto, M.D. 2012. Kualitas telur ayam konsumsi yang dibersihkan dan tanpa dibersihkan selama penyimpanan suhu kamar. Indonesia Medicus Veterinus. 1(3): 408-416.

Filazi, A., Sireli, U.T., \& Cadirci, O. 2005. Residues of gentamicin in eggs following medication of laying hens. British Poultry Science. 46(5):580-3.

Finata, R.P., Rudyanto, M. D., \& Suarjana, I.G.K. 2015. Pengaruh lama penyimpanan pada suhu kamar telur itik segar dan telur yang mengalami pengasinan berasal dari UKM Mulyo Mojokerto ditinjau dari jumlah Eschericia coli. Buletin Veteriner Udayana. 7(1): 4147.

Gaudin, V., Rault, A., Hedou, C., Soumet, C., \& Verdon, E. 2017. Strategies for the screening of antibiotic residues in eggs: comparison of the validation of the classical microbiological method with an immunobiosensor method. Food Additives \& Contaminants: Part A. 34(9): 1510-1527.

Ghasemian, S.H., Jalali, M., Hosseini, A., Narimani, T., Sharifzadeh, A., \& Raheimi, E. 2011. The prevalence of bacterial contamination of table eggs from retails markets by Salmonella spp., Listeria monocytogenes, Campylobacter jejuni and Escherichia coli in Shahrekord, Iran. Jundishapur Journal of Microbiology. 4(4): 249-253.

Goetting, V., Lee, K.A., Tell, L.A. 2011. Pharmacokinetics of veterinary drugs in laying hens and residues in eggs: a review of the literature. Journal of veterinary pharmacology and therapeutics. 34(6): 521-56.

Ha, N. R., Jung, I. P., La, I. J., Jung, H. S., \& Yoon, M. Y. 2017. Ultra-sensitive detection of kanamycin for food safety using a reduced graphene oxide-based fluorescent aptasensor. Scientific reports. 7(1): 1-10.

Hakimzadegan, M., Khosroshahi, M.K., \& Nasab, S.H. 2014. Monitoring of antibiotic residue in chicken eggs in Tabriz city by FPT. International Journal of Advanced Biological and Biomedical Research. 2(1): 132-140.

Haryuni, N., Widodo, E., Sudjarwo, E. 2015. Aktivitas antibakteri jus daun sirih (Piper bettle Linn) terhadap bakteri patogen dan kualitas telur selama penyimpanan. Jurnal Ternak Tropika. 16(1): 48-54.

Hargitai, R., Mateo, R., \& Torok, J. 2011. Shell thickness and pore rensity in relation to shell colouration female characterstic, and environmental factors in the collared flycatcher Ficedula albicollis. Journal Ornithol. 152(1):579-588.

Jondreville, C., Fournier, A., \& Feidt, C. 2011. Chemical residues and contaminants in eggs. Di dalam Van Immerseel F, Nys Y, Bain M, editor. Improving the safety and quality of eggs and egg products. Woodhead Publishing. hlm. 62-80.

Jones, D. R., Anderson, K. E., \& Guard, J. Y. 2012. Prevalence of coliforms, Salmonella, Listeria, and Campylobacter associated with eggs and the environment of conventional cage and free-range egg production. Poultry science, 91(5), 1195-1202.

Kan, C.A., \& Petz, M. 2000. Residues of veterinary drugs in eggs and their distribution between yolk and white. Journal of Agricultural and Food Chemistry. 48(12): 6397-6403. 
Khan, A., Rind, R., Shoaib, M., Kamboh, A. A., Mughal, G. A., Lakho, S. A., Malhi, K.K., Nizamani, A.R., \& Yousaf, A. 2016. Isolation, identification and antibiogram of Escherichia coli from table eggs. $J$. Anim. Health Prod, 4(1), 1-5.

Lubis, H.A., Suarjana, I.G.K., \& Rudyanto, M.D. 2012. Pengaruh suhu dan lama penyimpanan telur ayam kampung terhadap jumlah Escherichia coli. Indonesia Medicus Veterinus. 1(1): 144-159.

Mahmoudi, R, \& Norian, R. 2015. Determination of enrofloxacin residue in chicken eggs using FPT and ELISA methods. Journal Research Health. 5(2): 159164.

Mattjik, A.A., Sumertajaya, I.M. 2006. Perancangan percobaan dengan aplikasi SAS dan Minitab jilid I. Bogor (ID): IPB Pres.

Messens, W., Grijspeerdt, K., \& Herman, L. 2005. Eggshell penetration by Salmonella. World Poultry Science Journal. 61(1):71-85.

Meutia, N., Rizalsyah, T., Ridha, S., \& Sari, M.K. 2016. Residu antibiotika dalam air susu segar yang berasal dari peternakan di wilayah Aceh Besar. Jurnal Ilmu Ternak. 16(1):1-5.

Mulyani, S. 2013. Kimia dan bioteknologi dalam resistensi antibiotika. Seminar Nasional Kimia dan Pendidikan Kimia V. ISBN: 979363167-8. 20-33

Musgrove, M.T. 2011. Microbiology and safety of table eggs. Di dalam Van Immerseel F, Nys Y, Bain M, editor. Improving the safety and quality of eggs and egg products. Woodhead Publishing. hlm. 3-33.

Mutiarini, O., Wahyono, F., \& Susanti, S. 2019. Tingkat status pencemaran bakteri selama penyimpanan di jalur distribusi telur ayam layer. Jurnal Pengembangan Penyuluhan Pertanian. 13(24): 106-115.

Nugraha, A., Swacita, I.B.N., \& Tono, K.P.G. 2012. Deteksi bakteri Salmonella spp dan pengujian kualitas telur ayam buras. Indonesia Medicus Veterinus. 1(3): 320-329.

Nugroho, S., Purnawarman, T., \& Indrawati, A. 2015. Deteksi Salmonella spp. pada telur ayam konsumsi yang dilalulintaskan melalui Pelabuhan Tenau Kupang. Acta VETERINARIA Indonesiana. 3(1): 16-22.

Nurhidayah, Patriana, U., Ariyani, N., Triyulianti, N., Nugraha, U., Palupi, M.F., Ambarwati, Sari, R.A., Arimbi, D., \& Rusmiaty, E. 2014. Analisis residu beberapa golongan antibiotika pada telur ayam di 13 provinsi di Indonesia. Balai Besar Pengujian Mutu dan Sertifikasi Obat Hewan, Gunungsindur-Bogor. 1-11.

[Permentan] Peraturan Menteri Pertanian. 2017. Permentan Nomor 14/PERMENTAN/PK.350/5/2017 tentang Klasifikasi obat hewan. Jakarta (ID): Departemen Pertanian.

Petrie, A., \& Watson, P. 2013. Statistics for veterinary and animal science. John Wiley \& Sons.

Purwati, D., Djaelani, M. A., \& Yuniwarti, E. Y. W. 2015. Indeks kuning telur (IKT), haugh unit (HU) dan bobot telur pada berbagai itik lokal di Jawa Tengah. Jurnal Akademika Biologi. 4(2): 1-9.
Sakti, M.R., Rudyanto, M.D., \& Suarjana, I.G.K. 2012. Pengaruh suhu dan lama penyimpanan telur ayam lokal terhadap jumlah coliform. Indonesia Medicus Veterinus. 1(3): 394-407.

Shahbazi, Y., Hashemi, M., Afshari, A., \& Karami, N. 2015. A survey of antibiotic residues in commercial eggs in Kermanshah, Iran. Iranian Journal of Veterinary Science and Technology. 7(2): 57-62.

Singh, S., Yadav, A. S., Singh, S. M., \& Bharti, P. 2010. Prevalence of Salmonella in chicken eggs collected from poultry farms and marketing channels and their antimicrobial resistance. Food Research International. 43(8): 2027-2030.

Soekarto, S.T. 2013. Teknologi penanganan dan pengolahan telur. Bandung(ID): Alfabeta.

Stadelman, W.J., Newkirk, D., \& Newby, L. 2017. Egg science and technology. CRC Press.

Stepien-Pysniak, D. 2010. Occurrence of Gram-negative bacteria in hens' eggs depending on their source and storage conditions. Polish journal of veterinary sciences. 13(3): 507-513.

Suharyanto, S., Sulaiman, N.B., Zebua, C.K.N., \& Arief, I.I. 2016. Kualitas Fisik, Mikrobiologis, dan Organoleptik Telur Konsumsi yang Beredar di Sekitar Kampus IPB, Darmaga, Bogor. Jurnal Ilmu Produksi dan Teknologi Hasil Peternakan. 4(2): 275-279.

Taufik, E. 2007. Microbiological investigation of raw goat milk from commercial dairy goat farms in Bogor, Indonesia [tesis]. Chiang Mai (TH) Chiang Mai University dan Berlin (DE) Freie Universitat Berlin

Ulfah, I.M., Rastina, R., \& Abrar, M. 2017. Identifikasi cemaran Escherichia coli pada telur ayam ras yang dijual di swalayan daerah Darussalam kecamatan Syiah Kuala kota Banda Aceh. Jurnal Ilmiah Mahasiswa Veteriner. 1(4): 644-649.

[USDA] United States Department of Agriculture. Agricultural Marketing Service. Poultry Division. 1975. Egg grading manual. US Department of Agriculture.

Wijaya, V.P. 2013. Daya antibakteri albumen telur ayam kampung (Gallus Domesticus) dan ayam kate (Gallus Bantam) terhadap spesies bakteri coliform fekal pada cangkang telur. Jurnal Pendidikan Sains. 1(4): 365-374.

Xu, C., Kuang, H., \& Xu, L. 2019. Introduction of Immunoassays. Di dalam Food Immunoassay. Springer Nature Singapore Pte Ltd. Singapore. hlm. 1-14.

Yoshida, M., Kubota, D., Yonezawa, S., Nogawa, H., Yoshimura, H., \& Ito, O. 1976. Transfer of Dietary Kanamycin into Eggs and its Disappearance from Eggs and from the Liver and Bile. Japanese poultry science. 13(4): 129-135.

Yuwanta, T. 2010. Telur dan Kualitas Telur. Yogyakarta (ID): UGM Pr. 